\title{
Pendekatan Bermain untuk Menurunkan Perilaku Menghindar pada Anak yang Mengalami Trauma Pengobatan
}

\author{
Sumiati, Ambar Sulianti \\ UIN Sunan Gunung Djati Bandung, Jl. AH. Nasution No. 105 Bandung \\ e-mail: sumiatirahash@yahoo.co.id
}

\begin{abstract}
Trauma is emotional response that involve intense fear, helplessness, or horror. Trauma raises three reactions i.e. disrupt memory, avoidance behavior and emergence of physical disorders. Children love games. This study aimed to test the effect of the playing approach against avoidance behaviors in a child with treatment trauma due to chronic disease. This study used a quasi experimental by Single Subject Randomized Time Series Design. The research subject was a seven years old child who suffering chronic Lyme disease with a fist size swelling in her face who showed avoidance behaviour trauma. Lego, drawing, folding, and story telling have been choosen as playing approach. The avoidance behaviour were observed consists of treatment avoidance and laboratory avoidance. The data were analyzed using descriptive statistical analysis in the form of graphs. The results shown that playing method had lowering effect in both avoidance behaviors.
\end{abstract}

Keywords: playing method, avoidance behaviors, chronic, traumatic, children

\begin{abstract}
Abstrak
Trauma merupakan respon emosional yang melibatkan rasa ketakutan yang sangat, tidak berdaya, atau horor. Trauma memunculkan tiga reaksi yaitu ingatan yang mengganggu, perilaku menghindar dan munculnya gangguan fisik. Anak-anak menyukai permainan. Penelitian ini bertujuan mengetahui pengaruh metode pendekatan bermain terhadap perilaku menghindar pada anak yang mengalami trauma pengobatan karena penyakit menahun. Penelitian ini merupakan penelitian eksperimen kuasi dengan menggunakan Single Subject Randomized Time Series Design. Subjek penelitian ialah seorang anak berusia 7 tahun penderita penyakit menahun yaitu penyakit Lyme dengan pembengkakan sebesar kepalan tangan pada wajah dan mengalami trauma pengobatan sehingga menunjukkan perilaku menghindar pengobatan. Perlakuan yang diberikan berupa metode pendekatan bermain menggunakan permainan lego, menggambar, melipat, dan bercerita. Perilaku menghindar yang diamati yaitu menghindar dari terapi pengobatan dan pemeriksaan laboratorium. Data hasil penelitian dianalisis menggunakan analisis statistik deskriptif berupa grafik. Hasil penelitian menunjukkan metode pendekatan bermain menurunkan kedua perilaku menghindar.
\end{abstract}

Kata Kunci: bermain, perilaku menghindar, menahun, trauma, anak

\section{Pendahuluan}

Pengalaman traumatis sering melibatkan ancaman terhadap kehidupan atau keselamatan. Beberapa situasi yang membuat seseorang merasa terbebani bahkan melibatkan kerusakan fisik. Trauma terjadi berdasarkan pengalaman emosional seseorang memaknai suatu peristiwa yang menjadi pemicu seseorang tersebut memiliki trauma psikologis.

Trauma didefinisikan oleh American Psychological Association (APA) sebagai respon emosional seseorang terhadap suatu peristiwa yang sangat negatif. Trauma adalah reaksi normal terhadap peristiwa yang mengerikan, efek dapat begitu parah sehingga mereka mengganggu kemampuan individu untuk hidup normal. Secara umum, ketika seseorang mengalami trauma apapun peristiwa yang melatar belakanginya reaksi yang muncul dapat dikategorikan menjadi tiga hal yaitu ingatan yang mengganggu, selalu meng-hindar, dan munculnya gangguan fisik. 
Trauma yang dialami di masa kecil, dapat memiliki efek yang parah dan bertahan lebih lama. Anak-anak yang mengalami trauma, melihat dunia sebagai tempat yang menakutkan dan berbahaya. Ketika trauma masa kecil yang tidak terselesaikan, rasa takut yang mendasar dan ketidakberdayaan membawa mereka mengalami trauma lebih lanjut.Trauma dapat disebabkan oleh sebuah peristiwa negatif yang menyebabkan dampak yang menetap pada ketidakseimbangan mental dan emosional anak. Di antara sumber trauma yang mengganggu perasaan anak dari mulai rasa aman dan keselamatan hingga membuat anak tersebut mengalami peristiwa trauma adalah menderita penyakit menahun.

Seseorang yang menderita penyakit menahun dan terjadi pada usia sekolah akan menimbulkan perasaan yang tidak nyaman, ketakutan maupun rasa tidak percaya diri saat bertemu keluarga dan temantemannya. Seperti kasus yang terjadi pada subjek A. Ia menderita penyakit Lyme selama 2 tahun. Proses pengobatan yang berlangsung dalam waktu lama membuat subjek trauma dengan suasana rumah sakit seperti dokter, obat-obatan, perawat, dan segala hal yang berhubungan dengan pengobatan dan berakibat pada terhambatnya tindakan medis yang dilakukan. Ia menunjukkan perilaku meng-hindar untuk diperiksa dokter, menghindar untuk diambil darah, bahkan saat dokter atau perawat masuk ruangan, A langsung menangis. Perilaku tersebut menjadi sebuah gangguan bagi A maupun bagi orang di sekitarnya. Pada dasarnya setiap gang-guan akan mengakibatkan perilaku yang maladaptif. Salah satu perilaku maladaptif yang diakibatkan oleh trauma adalah adanya perilaku menghindar yang pada akhirnya dapat menghambat produktivitas, interaksi sosial, dan bahkan perkembangan kepribadian individu yang mengalaminya.

Kondisi kesehatan anak A semakin parah karena menghindari terapi pengobatan. A mengalami kesakitan dan kesulitan menggerakkan anggota badannya karena perjalanan penyakitnya bertambah berat. Jika tetap dibiarkan seperti itu dengan tetap menuruti keinginan anak untuk tidak melakukan pengobatan maka selain penyakitnya tersebut semakin parah, A juga akan memiliki beban psikis dalam menjalani kehidupan dan tahap perkembangannya akan terhambat. Untuk mendukung pengobatan terhadap A, dibutuhkan metode pendekatan psikologis yang bertujuan mengalihkan pikiran subjek kepada hal yang membuatnya senang. Salah satu metode pendekatan yang dapat digunakan untuk mengatasi trauma pada anak ialah metode bermain.

Menurut Supartini (2004) terapi bermain merupakan terapi pada anak yang menjalani hospitalisasi. Pada saat dirawat di rumah sakit, anak mengalami berbagai perasaan tidak menyenangkan, seperti marah, takut, cemas, sedih dan nyeri. Dalam kasus seperti ini, diperlukan pendekatan untuk mengobati stres maupun disfungsi yang disebabkan oleh peristiwa traumatis dan untuk mengembalikan individu kepada keadaan kondisi emosi yang sehat. Dengan melakukan permainan anak diharapkan akan terlepas dari ketegangan dan stres yang dialaminya. Hal tersebut disebabkan karena dengan melakukan permainan, anak akan dapat mengalihkan rasa sakitnya pada permainan dan terjadi relaksasi melalui perasaan senang saat bermain. Berdasarkan fenomena yang telah diuraikan, peneliti tertarik untuk meneliti pengaruh dari pendekatan bermain terhadap perilaku menghindar pada anak yang menderita penyakit menahun

Bermain merupakan hal yang disukai anak. Pendekatan bermain dapat dilakukan oleh berbagai pihak di rumah sakit. Peneliti membatasi masalah yang dibahas, yaitu apakah pendekatan bermain menurunkan perilaku menghindar pada anak yang mengalami trauma pengobatan? 


\section{Metode Penelitian}

Penelitian ini menggunakan metode eksperimen yang dilakukan dengan memanipulasi yang bertujuan untuk mengetahui akibat manipulasi terhadap perilaku individu yang diamati (Latipun, 2002). Penelitian ekpserimen ini menggunakan desain single subject randomized time series yang memfokuskan pada data individu sebagai sampel penelitian yaitu untuk melihat hasil ada tidaknya pengaruh atau perubahan yang terjadi dari suatu perlakuan yang diberikan kepada subyek secara berulang-ulang dalam kurun waktu tertentu misalnya perminggu, perhari, perjam, atau permenit (Arikunto, 2002). Sebelum diberi perlakuan, kelompok diberi pretest sampai 3 kali dengan maksud untuk mengetahui kestabilan dan keadaan kelompok sebelum diberi perlakuan. Bila hasil pretest selama 3 kali ternyata belum mencapai keadaan yang stabil, tidak menentu dan tidak konsisten maka dilakukan pretest sampai keadaan subjek dapat diketahui secara konsisten dan stabil maka baru diberi treatment atau perlakuan. Desain penelitian ini hanya menggunakan satu kelompok saja sehingga tidak memerlukan kelompok kontrol. Rancangan penelitian eksperimen ini dapat dilihat dalam bentuk tabel 1 berikut:

Tabel 1

Single Subject Randomized Time Series Design

\begin{tabular}{ll}
\hline Pretest & \multicolumn{1}{c}{ Postest } \\
\hline \multirow{3}{*}{$\mathrm{Y}_{1} \mathrm{Y}_{2} \mathrm{Y}_{3}$} & $(\mathrm{X})$ \\
& $\mathrm{Y}_{4} \mathrm{Y}_{5} \mathrm{Y}_{6} \mathrm{Y}_{7} \mathrm{Y}_{8}$ \\
& $\mathrm{Y}_{9} \mathrm{Y}_{10} \mathrm{Y}_{11} \mathrm{Y}_{12}$ \\
& $\mathrm{Y}_{13} \mathrm{Y}_{14} \mathrm{Y}_{15} \mathrm{Y}_{16}$ \\
& $\mathrm{Y}_{17} \mathrm{Y}_{18} \mathrm{Y}_{19} \mathrm{Y}_{20}$ \\
\hline
\end{tabular}

Keterangan:

$\mathrm{X}$ : Terapi bermain yang diberikan sebagai intervensi (menggambar, lego, melipat, bercerita)

Y: Hari dilaksanakannya pengambilan data

Subjek dalam penelitian ini adalah seorang anak perempuan berusia 8 tahun yang menderita penyakit Lyme selama dua tahun dan memiliki riwayat trauma pengobatan, dan sedang melakukan pengobatan di Klinik dengan rawat inap di Cikampek, Karawang, Jawa Barat.

Wong (2000) mendefinisikan ber-main sebagai cerminan kemampuan fisik, intelektual, emosional dan sosial dan bermain merupakan media yang baik untuk belajar karena dengan bermain, anak akan berkata-kata, belajar menyesuaikan diri dengan lingkungan melakukan apa yang dapat dilakukan, dan mengenal waktu, jarak, serta suara. Secara operasional pendekatan bermain pada penelitian ini adalah kegiatan berupa bermain lego, menggambar menggunakan pinsil dan pinsil warna, melipat kertas berwana dan bercerita tentang kisah nabi.

Perilaku menghindar secara umum adalah salah satu reaksi yang muncul akibat adanya peristiwa trauma. Secara konseptual perilaku menghindar adalah situasi dimana seseorang menarik diri dari situasi sosial terutama yang mengalami traumatis yang pernah dialami (Pickett, 1998). Ketika berhadapan dengan suatu situasi yang sama persis ketika peristiwa itu muncul, secara langsung orang tersebut akan menghindarinya. Secara operasional perilaku menghindar adalah perilaku penolakan yang dilakukan subjek terhadap proses pengobatan karena pengalaman akan traumatis yang dialamunya terhadap pengobatan.

Dalam operasionalisasi penelitian ini, perilaku menghindar dilihat dari penurunan skor grafik yang akan mengukur 2 perilaku menghindar yang diamati pada subjek penelitian yaitu: menghindar dari pemberian terapi dan dari pemeriksaan penunjang laboratorium. Perilaku menghindar dari pemberian terapi dijabarkan dalam skoring yang dapat dilihat pada tabel 2. 
Tabel 2

Skor Perilaku Menghindar dari Pemberian Terapi

\begin{tabular}{cl} 
Skor & \multicolumn{1}{c}{$\begin{array}{c}\text { Perilaku Menghindar } \\
\text { Menghindar Pemberian Terapi }\end{array}$} \\
\hline 6 & $\begin{array}{l}\text { Menolak melakukan terapi sambil } \\
\text { menangis }\end{array}$
\end{tabular}

5 Mau melakukan terapi sambil dipangku orang tua subjek, namun menangis

4 Mau melakukan terapi sambil dipangku orang tua subjek, tanpa menangis

3 Mau melakukan terapi ditemani orang tua di kamar terapi namun menolak melakukan posisi tertentu, tanpa menangis

2 Mau melakukan terapi dengan posisi lengkap di ruang terapi dengan di temani orang tua, tanpa menangis

1 Mau melakukan terapi di ruangan terapi dengan posisi lengkap, tanpa ditemani orang tua, dan tanpa menangis

0 Meminta untuk melakukan terapi, melakukan terapi di ruangan terapi, pergi ke ruangan terapi sendiri

Semakin menurun nilai skor grafik, maka semakin menurun juga perilaku menghindar subjek.Jika skor grafik semakin meningkat maka perilaku menghindar subjek semakin meningkat. Adapun perilaku menghindar dari pemberian terapi dijabarkan dalam skoring yang dapat dilihat pada tabel 3 .

Tabel 3

Skor Perilaku Menghindar dari Penunjang Laboratorium

\begin{tabular}{clc}
\hline Skor & \multicolumn{1}{c}{$\begin{array}{c}\text { Perilaku Menghindar Dari } \\
\text { Pemeriksaan Penunjang } \\
\text { Laboratorium }\end{array}$} \\
\hline 6 & $\begin{array}{l}\text { Selalu menangis saat petugas } \\
\text { laboratorium datang dengan } \\
\text { tangisan yang keras dan berteriak }\end{array}$ \\
& $\begin{array}{l}\text { selama }>2 \text { jam } \\
5\end{array}$ & Menangis dengan tangisan yang \\
\hline
\end{tabular}

keras dan berteriak saat petugas laboratorium datang selama 1-2 jam

4 Menangis dengan suara pelan tanpa berteriak selama 1-2 jam

3 Menangis sebentar dengan suara pelan $<30$ menit

2 Tidak menangis, tidak menjawab pertanyaan petugas laboratorium, namun tidak menolak tindakan pemeriksaan laboratorium

1 Tersenyum saat petugas laboratrium datang dan menjawab pertanyaan petugas laboratorium dengan anggukan, mau diberikan tindakan

0 Tersenyum saat petugas datang, menjawab pertanyaan dari petugas secara verbal, mau diberikan tindakan

Selain variabel yang dikur, dalam penelitian eksperimen terdapat variabel terkontrol dan variabel tidak terkontrol. Adapun variabel terkontrol pada penelitian ini adalah: (a) waktu pengukuran yang dilakukan selama 14 hari, dilakukan pada waktu yang sama yaitu pukul 14.00 WIB, (b) situasi ruangan, penelitian dan pengambilan data dilakukan di ruangan rawat inap klinik $\mathrm{X}$ dengan luas ruangan kurang lebih $2 \times 3 \mathrm{~m}$, dengan fasilitas AC dan tempat tidur, (c) alat dan bahan untuk bermain yaitu berupa alat bermain yang digemari subjek, yaitu: lego, buku gambar, pensil warna, buku cerita dan kartu origami. Sedangkan variabel yang tidak terkontrol: (a) kondisi kesehatan mengingat perjalanan yang kronis dan trauma pengobatan yang dialami subjek, (b) keadaan mood subjek (suasana hati), (c) lingkugan berupa bencana alam seperti banjir.

Data dikumpulkan dalam bentuk pengamatan mengenai perilaku subjek dengan diberikan intervensi berupa terapi bermain dengan metode menggambar, lego, melipat dan bercerita. Pengumpulan data tersebut dilakukan selama 20 hari di klinik X Karawang, Jawa Barat. 
Pengolahan data dalam peneltian ini menggunakan statistik deskriptif berupa penyajian data hasil penelitian dalam bentuk grafik.Teknik ananlisis ini dipilih sesuai dengan rancangan peneltian yaitu subjek peneltian hanya terdiri dari 1 orang. Penarikan kesimpulan mengenai penelitian dilihat berdasarkan ada tidaknya penurunan grafik dari kondisi pretest menuju postest.

\section{Hasil dan Pembahasan}

Hasil penelitian diperoleh melalui datadata pengamatan kegiatan subjek selama 20 hari berkaitan dengan perilaku menghindar subjek yang dikelompokkan ke dalam 2 kategori yaitu menghindar dari terapi dan pemeriksaan laboratorium. Hasil pengamatan perilaku menghindar dapat dilihat pada grafik berikut ini.

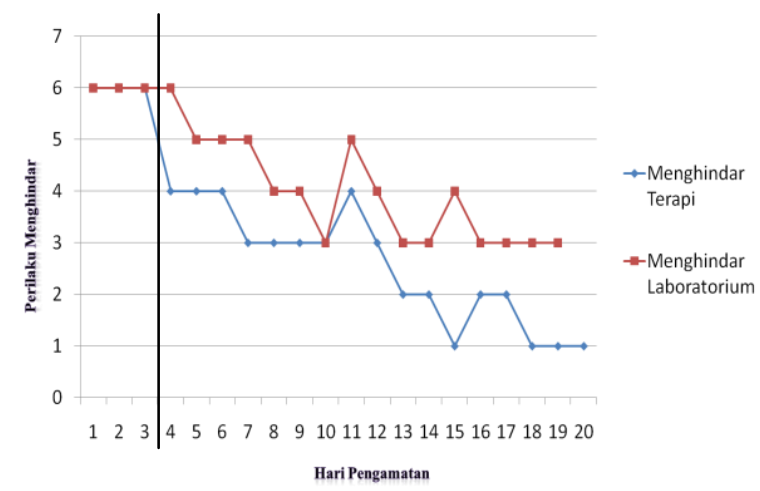

Gambar 1. Perilaku menghindar dan pemberian terapi.

Grafik di atas menunjukkan skor perilaku menghindar subjek terhadap pemberian terapi yang bergerak dari 6 sampai dengan 1. Sebelum diberikan perlakuan, skor perilaku menghindar subjek berada pada skor 6 , dengan perilaku yang ditunjukkan subjek adalah selalu menangis lebih dari 2 jam dan menolak melakukan terapi. Pada hari ke-2 dan ke-3 perilaku menghindar subjek menurun pada skor 5 yang mana perilaku yan ditunjukkan adalah mau melakukan terapi sambil dipangku ayah dan kadang-kadang menangis selama 1 sampai 2 jam. Pada hari ke-4, ke-5, dan ke-6 dengan pemberian treatment bermain perilaku menghindar yang ditunjukkan subjek menurun pada skor 4 dengan perilaku mau melakukan terapi sendiri di kamar namun menolak melakukan posisi tertentu, kadang-kadang menangis tanpa berteriak kurang dari 1 jam.

Selanjutnya pada hari ke-7, ke-8, ke-9, dan ke-10 subjek mencapai skor yang menurun dari hari sebelumnya yaitu dengan skor 3 yang berarti subjek mau melakukan terapi dengan posisi lengkap di kamarnya sendiri, tanpa menangis. Pada hari ke-11 terjadi peningkatan skor perilaku menghindar subjek dari pemberian terapi, diakibatkan tindakan yang dilakukan oleh pihak laboratorium yang membuat subjek kembali menangis tanpa berteriak kurang dari 1 jam dan menolak untuk melakukan terapi di ruang terapi.

Pada hari ke-12 dan ke-13 skor subjek menurun kembali yaitu berada pada skor 3 . Pada hari ke-14 subjek me-nunjukkan perilaku mau melakukan terapi dengan posisi lengkap di ruang terapi namun masih ditemani ayahnya tanpa menangis dengan skor 2.Pada hari ke-15 perilaku menghindar subjekmenurun pada skor 1 yang berarti subjek mau melakukan terapi di ruangan terapi dengan posisi lengkap, tanpa ditemani ayahnya dan juga tanpa menangis.Pada hari ke-16 dan ke-17 subjek mengalami peningkatan skor dari hari sebelumnya yaitu pada 2, dikarenakan subjek tiba-tiba mengalami sakit pada giginya, dan pada saat di terapi ada penambahan alat yan digunakan untuk menerapi yang berbentuk seperti jarum menyebabkan subjek mau melakukan terapi dengan ditemani ayahnya. Setelah dilakukan pengobatan trehadap giginya tersebut subjek mau melakukan kembali terapi dengan tidak ditemani ayahnya dan dengan posisi lengkap tanpa menangis pada hari ke-19 dan hari ke-20.

Untuk perilaku menghindar dari pemeriksaan laboratorium, sebelum diberikan treatment, perilaku subjek berada pada skor tertinggi yaitu 6.Dalam hal ini penurunan terjadi secara perlahan, terlihat dari bentuk grafik yang naik turun dan nilai 
skor terendah hanya mencapai 3. Kenaikan grafik terjadi pada hari ke-11 dan hari ke15 , namun pada hari ke-16 grafik kembali menurun pada skor 3, dimana skor tersebut bertahan sampai hari terakhir, yaitu hari ke20. Pada hari tersebut setiap penunjang laboratorium datang, subjek menunjukkan perilaku kadang-kadang menangis dengan suara pelan kurang dari 30 menit.

Hasil penelitian yang dilakukan selama 20 hari pengamatan mengenai perilaku menghindar subjek menunjukkan bahwa pendekatan bermain menurunkan perilaku menghindar subjek baik dari terapi maupuan dari pemeriksaan laboratorium. Perasaan trauma atau takut akibat dari hospitalisasi yang dialami oleh anak karena menghadapi stresor yang ada di lingkungan rumah sakit. Dalam beberapa studi yang dilakukan ditemukan bukti bahwa hospitalisasi anak dapat menjadi suatu permasalahan yang menimbulkan trauma baik pada anak maupun orang tua sehingga menimbulkan reaksi tertentu yang akan sangat berdampak pada kerjasama anak dan orang tua dalam perawatan anak selama di rumah sakit (Halstroom \& Elander, 1997; Brewis, 1995; Brennam, 1994). Lingkungan rumah sakit merupakan penyebab stres bagi anak dan orang tuanya, baik lingkungan fisik rumah sakit seperti bangunan atau ruang rawat, alat-alat, bau yang khas, pakaian putih petugas kesehatan maupun lingkungan sosial, seperti sesama pasien anak, ataupun interaksi dan sikap petugas kesehatan itu sendiri (Supartini, 2004).

Pendekatan bermain yang diberikan dalam penelitian ini adalah metode lego, menggambar, melipat, dan bercerita. Pemberian treatment seperti telah dibahas sebelumnya bertujuan untuk mengalihkan rasa trauma subjek terhadap pengobatan menjadi sebuah hal yang menyenangkan.Pemilihan metode bermain ini pun memiliki tujuan tertentu dalam penurunan perilaku menghindar subjek.

Metode lego memberikan beberapa manfaat seperti telah disebutkan oleh salah satu promotor mainan lego Ardi Lazuardi (2012), yaitu pertama aspek kognisi, yang akan melatih kreativitas dan menciptakan daya imajinasi seseorang. Kedua menyatukan ide, seorang anak akan saling bertukar ide untuk mewujudkan kreasi imajinasi. Ketiga untuk mengajar anak bersosialisasi, dimana dengan lego ini aspek social anak akan berkembang dan anak akan belajar untuk berkomunikasi dengan baik. Berdasarkan penelitian yang dilakukan, saat pemberian metode lego ini subjek mampu menmbuat tokoh nenjia go yang ia susun sendiri menunjukkan munculnya daya kreativitas subjek. Kemudian saat subjek tidak bisa mengerjakan atau ada suatu bagian lego yang hilang, subjek bertanya kepada peneliti serta orang yang ada di sekitarnya. Hal tersebut menunjukkan adanya penyatuan ide serta adanya suatu komunikasi yang terjalin antara subjek dengan orang lain.

Melipat atau origami adalah suatu teknik berkarya seni/kerajinan tangan yang umumnya dibuat dari bahan kertas, dengan tujuan untuk menghasilkan aneka bentuk mainan, hiasan, benda fungsional, alat peraga, dan kreasi lainnya. Melipat menimbulkan suatu karya yang menyenangkan bagi anak-anak.Pemilihan metode ini pun di sesuaikan dengan kemampuan subjek, dimana keadaannya yang sulit menggerakkan tangannya. Pada saat melipat origami, subjek kadang-kadang menunjukkan ekspresi tersenyum dan menunjukkan hasil karyanya kepada orang yang ada disekitarnya, bahkan subjek kadang-kadang memainkan hasil lipatan yang dia buat seperti kapal-kapalan.

Menggambar ini merupakan ekspresi segala sesuatu yang muncul dalam kesadaran anak pada saat itu. Gambar yang diekspresikan dapat bersifat simbolik dan bukan tiruan bendanya sendiri secara langsung (Moeslichatoen, 2004:41). Pada hakekatnya menggambar ini adalah pengungkapan seseorang secara mental dan visual dari apa yang dialaminya dalam bentuk garis dan warna. Pada saat selesai 
menggambar, seringkali subjek menceritakan hasil gambarnya. Salah satunya saat subjek menceritakan mengenai gambar kucingnya, subjek menceritakan kucingnya yang pernah tertabrak tetapi sembuh kembali karena segera dibawa ke dokter hewan. Salah satunya juga saat ia selesai menggambar ular, ia tiba-tiba bercerita mengenai ayahnya yang takut terhadap ular. Dari hal tersebut, peneliti mengkaitkan dengan keadaan subjek yang kemudian menceritakan ulang kepada subjek bahwa subjek juga harus berani seperti kucingnya yang berani terhadap dokter dan jangan seperti ayahnya yang penakut.

Bercerita menurut Musfiroh (2005) ditinjau dari beberapa aspek, manfaat bercerita untuk membantu pembentukan pribadi dan moral anak, menyalurkan kebutuhan imajinasi dan fantasi, memacu kemampuan verbal anak, merangsang minat menulis anak, merangsang minat baca anak, membuka cakrawala pengetahuan anak. Pada saat subjek diberikan cerita oleh peneliti, subjek terlihat mendengarkan dan kemudian menanyakan apa yang tidak ia mengerti seperti kata-kata asing. Subjek kadangkadang mampu mengungkapkan kembali intisari dari apa yang diceritakan, tapi kadang-kadang ia juga hanya menjawab dengan ucapan tidak tahu. Intisari dari apa yang telah diceritakan seringkali dikaitkan dengan keadaan subjek, seperti harus mau menepati janji untuk makan, harus jadi pemberani terhadap pengobatan karena dengan bukan suatu hal yang harus ditakuti, dan lain sebagainya.

Subjek yang menunjukkan perilaku menghindar terhadap orang lain terutama yang berhubungan dengan rumah sakit, maka dengan metode pendekatan bermain lego, melipat, menggambar dan bercerita ini mampu mempengaruhi perilaku menghindar subjek dengan mengalihkan trauma yang ia alami dengan kesenangan yang ia rasakan dari bermain, dan secara perlahan subjek mampu membangun komunikasi dengan orang lain yang berada di rumah sakit tersebut, hingga tidak beruasaha menarik dirinya kembali dari lingkungan sosial di rumah sakit. Penurunan perilaku menghindar dari terapi lebih besar daripada menghindar dari pemeriksaan laboratorium. Hal ini disebabkan karena rasa nyeri sewaktu menjalani pemeriksaan laboratorium yaitu sewaktu diambil darah sehingga perlu waktu lebih lama untuk menurunkan perilaku menghindar dari pemeriksaan laboratorium.

\section{Simpulan dan Saran}

Berdasarkan hasil penelitian yang telah dilakukan, dapat disimpulkan bahwa terdapat metode pendekatan bermain (menggambar, lego, bercerita dan melipat) menurunkan perilaku menghindar subjek yang memiliki trauma pengobatan akibat penyakit menahun. Hal tersebut ditunjukkan dari menurunnya grafik perilaku menghindar baik menghindar dari terapi maupun menghindar dari pemeriksaan laboratorium. Perilaku menghindar terhadap terapi lebih cepat menurun dibandingkan menghindar dari pemeriksaan laboratorium.

Saran dari penelitian ini yaitu perlu dilakukan penelitian eksperimen lebih lanjut dengan jumlah sampel yang besar dan waktu yang lebih lama tentang pengaruh metode pendekatan bermain terhadap penurunan trauma pada anak dengan penyakit menahun. Selain itu perlu dilakukan pengujian pendekatan bermain lainnya terhadap perilaku menghindar anak akibat trauma pengobatan penyakit menahun. Bagi petugas di rumah-rumah sakit, perlu menerapkan metoda pendekatan berbasis bermain kepada anak-anak yang dirawat di rumah sakit.

\section{Daftar Pustaka}

Alfiyanti, D., Hartiti, T., \& Samiasih, Amin. (2007). Pengaruh terapi bermain terhadap tingkat kecemasan anak usia prasekolah selama tindakan 
keperawatan di ruang Lukman RS Roemani Semarang. Jurnal

Keperawatan, 1(1), 35-44, diakses dari http://jurnal.unimus.ac.id

Alwi, dkk. (2005). Kamus besar bahasa indonesia. Jakarta: Departemen Pendidikan Nasional Balai Pustaka

Andriana, D. (2011). Tumbuh kembang dan terapi bermain pada anak. Jakarta: Salemba Medika

Bachri, S. B. (2005). Penembangan kegiatan bercerita, teknik, dan prosedurnya. Jakarta: Departemen Pendidikan dan Kebudayaan

Cook, G. C. (1993). Manson's tropical diseases. London: W.B. Saunders Company

Prasetyono, D. S. (2007). Membedah psikologi bermain anak. Yoyakarta: Think

Graziano, A. M., Raulin, M. L. (2000). Research methods a process of inquiry (4th ed.). Boston: Allyn \& Bacon

Hurlock, E. (2004). Psikologi perkembangan. Jakarta: PT. Gramedia Pustaka

Lonergan, B. A. (1999). The development of trauma therapist: A qualitative studi of the therapist's perspectives and experiences. Colorado: Counselling Psychology.

Moeslichatoen. (2004). Metode pengajaran. Jakarta: Rineka Cipta

Nurhayati, Y. (2010). Bermain dengan media lego. Yogyakarta: Diva Press
Piaget, J. P.. (1999). Dreams and imitation in childhood. New York: WW. Norton \& Company

Ray. (2007). Impact of play therapy on parent child relationship stress at a mental health training setting. British Journal of Guidance \& Cuonselling, 36(2)

Romawati, T. (2014) Penerapan metode bcm (bermain, cerita, menyanyi) dalam pembelajaran pai untuk meningkatkan keaktifan siswa kelompoka tk masyitoh greges semester 2 tahun 2013/2014. Skripsi tidak diterbitkan. Fakultas Tarbiyah dan Keuruan UIN Sunan Kali Jaga Yoyakarta. Diakses melalui http://digilib.uin-suka.ac.id

Soetjiningsih. (2002). Tumbuh kembang anak. Jakarta: EGC.

Stamm, B. H. (1999). Secondary traumatic stress. self care issues for clinicians, researchers \& educators. MD: Sidran Press.

Strickland, G. T. (2000). Hunter's tropical medicine and emerging infectious diseases (8th ed.). New York: W.B Saunders Company

Sugiyono. (2013). Metode penelitian pendidikan: Pendekatan kuantitatif, kualitatif, dan $R \& D$. Bandung: Alfabeta

Tedjasaputra. (2001). Bermain mainan untuk anak usia dini. Jakarta: Gasindo

Whaley \& Wong. (2002). Pedoman klinis keperawatan pediatrik. Jakarta: EGC 